\title{
ANOMALOUS COLORATION IN AN ATLANTIC SPOTTED DOLPHIN (STENELLA FRONTALIS) FROM SOUTHEASTERN BRAZIL
}

\author{
LODI, L. ${ }^{1 *} \&$ BOROBIA, M. ${ }^{2}$
1 - Instituto Aqualie, Av. Dr. Paulo Japiassu Coelho 714, SI. 206, Juiz de Fora, MG, Brazil, 36033-310.
2 - 11-5915 Vedder Road, Chilliwack, British Columbia, Canada, V2R 1 C3. \\ *Corresponding author: lilianelodi@gmail.com
}

\begin{abstract}
Lodi, L. \& Borobia, M. (2013) Anomalous coloration in an Atlantic Spotted Dolphin (Stenella frontalis) from Southeastern Brazil. Braz. J. Aquat. Sci. Technol. 17(2):NB1-3. eISSN 1983-9057. DOI: 10.14210/bjast.v17.n2.pNB1-3. This note reports the first published account of an atypical coloration condition known as pied or piebald for the Atlantic spotted dolphin (Stenella frontalis). The opportunistic sighting was made at close range between Cabo de São Tomé and Cabo Frio, Campos Basin, southeastern Brazil, approximately $60 \mathrm{~km}$ offshore. It is important to publish observations about pigmentation disorders so that a proper assessment and further insights into the ecological and physiological implications of this condition in cetaceans can be evaluated in the future.
\end{abstract}

Keywords: Stenella frontalis, coloration, piebald.

Anomalous coloration conditions occur with low frequency in marine mammals (e.g., Fertl et al., 1999; Fertl et al., 2004; Fertl \& Rosel, 2008; Abreu et al., 2013). Abnormal color variations can occur due to an excess, or a lack of, melanin in part of or the entire body. Such conditions have been documented as: albinism which is a complete lack of pigmentation (i.e., hypopigmentation) in the eyes, skin and hair; leucism which is characterized by partial or total absence of pigmentation such that the body appears with anomalous white coloration but the animal still possess normally colored eyes; and melanism which is an increased amount of black (including or nearly black) pigmentation. A hypo-pigmentation pattern known as pied or piebald, is the localized absence of pigment resulting in irregular patches of light color on an animal that otherwise has normal coloring and patterning. In this case the ratio of light color to normal-colored skin can vary considerably (Fertl \& Rosel, 2008; Acevedo et al., 2009).

On November 1, 2011, the crew of the GSO Marechal Rondon of Geodata Offshore Services videoed and photographed a group of six Atlantic spotted dolphins, Stenella frontalis, for 22 minutes (starting 12h42min). The sighting was made at close range between Cabo de São Tomé (2158'53.89"S; $\left.40^{\circ} 58^{\prime} 38.72 " \mathrm{~W}\right)$ and Cabo Frio (22 ${ }^{\circ} 53^{\prime} 6.13^{\prime \prime} \mathrm{S}$; $\left.42^{\circ} 0^{\prime} 0.80^{\prime \prime} \mathrm{W}\right)$, Campos Basin, southeastern Brazil, approximately $60 \mathrm{~km}$ offshore during good sighting conditions. This vessel carries out geophysical surveys and it was in transit during this opportunistic encounter, with dolphins travelling at the surface when the group was first sighted. A smaller sized individual, likely a subadult or young adult, with aberrant pigmentation accompanied the five normally-pigmented adults (Figure
1A). The dolphin with the anomalous color pattern (resembling a patchwork pattern) maintained constant close association with the normally pigmented adults of its group and repeatedly leaped before the ship bow on several occasions (Figures $1 \mathrm{~A}$ and $\mathrm{B}$ ). The degree of pigmentation observed in this individual, with an incomplete absence of pigmentation, is consistent with the description of piebaldism (Fertl \& Rosel, 2008).

Species identification was possible due to characteristics visible in images (photographs and video) including a diagnostic external feature of $S$. frontalis, a spinal blaze sweeping up into the dorsal cape; this distinguishes it from the very similar pantropical spotted dolphin, S. attenuata (Gray, 1846), also found in the tropical Atlantic. In addition, the peduncle of individuals sighted did not exhibit the division into darker upper and lighter lower halves present in S. attenuata (Perrin, 2002). With the exception of the piebald individual, members of the group were not spotted, as this species is not always spotted, presenting geographical variation in size and degree of spotting. It can be heavily or lightly spotted, with no spots in their ventral area or entirely unspotted as an adult (Perrin et al., 1987; Perrin, 2002).

Atlantic spotted dolphins are endemic to the tropical and warm-temperate waters of the Atlantic Ocean. On the east coast of South America, S. frontalis shows discontinuous distribution presenting two geographically isolated populations in southern $\left(33^{\circ} \mathrm{S}\right.$ to $18^{\circ} \mathrm{S}$ ) and northern Brazil (north of $06^{\circ} \mathrm{S}$ ) (Moreno et al., 2005; Danilewicz et al., 2013).

The present note constitutes the first published account of piebaldism for the Atlantic spotted dolphin. Reports of unusual coloration in $S$. frontalis are rare with a single previous record of an individual with 
anomalously white coloration from Pico, Azores (Fertl et al., 1999). Cases of piebald pigmentation in other cetaceans have been recorded, for instance for dusky dolphins (Lagenorhynchus obscurus) from Peruvian waters (Van Waerebeek, 1993), Pacific white-sided dolphins (Lagenorhynchus obliquidens) in Volcano Bay, Japan (Tsutsui et al., 2001), common dolphins (Delphinus sp.) off northern New Zealand (Stockin \& Visser, 2005) and harbour porpoises (Phocoena phocoena) in Turkish waters (Tonaya et al., 2012).

Although the causes of atypical color patterns are uncertain, more observations are required for a proper assessment of the ecological and physiological implications of this condition in cetaceans.

\section{ACKNOWLEDGEMENTS}

We would like to thank Dagmar Fertl, Daniel Palacios, Patricia Rosel, Robert L. Pitman, Thomas Jefferson and William F. Perrin for their contribution towards defining the anomalous coloration reported here. Angelo Lima and Gilberto Dias kindly provided the photographs and video, through the courtesy of Bia Hetzel. Dagmar Fertl and one anonymous reviewer improved the manuscript and provided valuable suggestions.
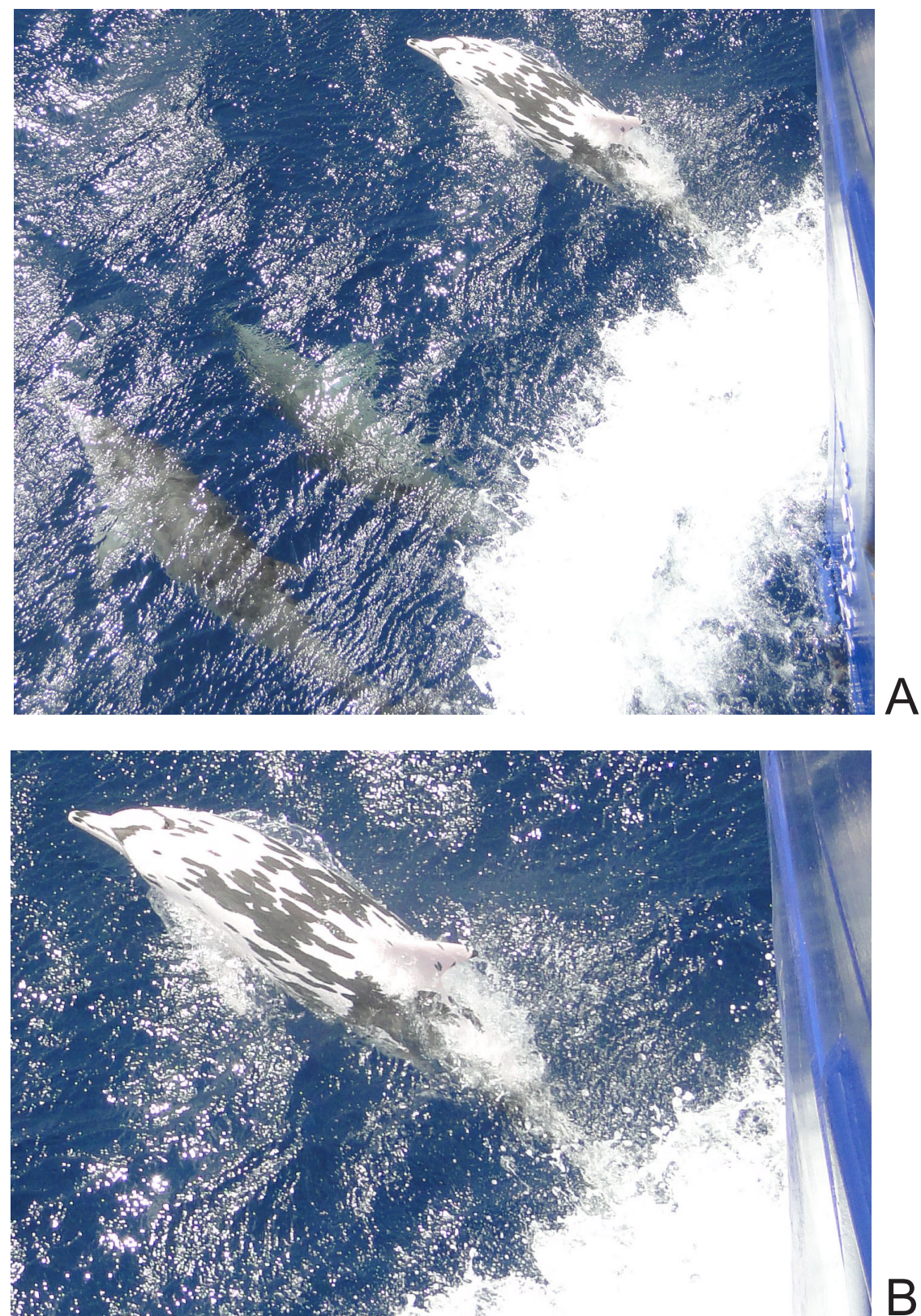

Figure 1 - Atlantic spotted dolphin (Stenella frontalis) observed at Campos Basin, Rio de Janeiro, presenting a rare coloration pattern consistent with the description of piebaldism. Photo: Angelo Lima. 


\section{REFERENCES}

Abreu, M.S.L.; Machado, R.; Barbieri, F.; Freitas, N.S. \& Oliveira, L. 2013. Anomalous colour in Neotropical mammals: a review with new records for Didelphis sp. (Didelphidae, Didelphimorphia) and Arctocephalus australis (Otariidae, Carnivora). Braz. J. Biol.73(1): 185-194.

Acevedo, J.; Torres, D. \& Aguayo-Lobo, A. 2009. Rare piebald and partially leucistic Antarctic fur seals, Arctocephalus gazella, at Cape Shirreff, Livingston Island, Antarctica. Polar Biol. 32(1): 41-45.

Danilewicz,D.; Ott, P.H.; Secchi, E.R. \& Andriolo, A. 2013. Occurrence of the Atlantic spotted dolphin, Stenella frontalis, in southern Abrolhos Bank, Brazil. Mar. Bio. Rec. 6(e6): 1-3. DOI: 10.1017/S1755267212000929

Fertl, D.; Barros, N.B.; Rowlett, R.A.; Estes, S. \& Richlen, M. 2004. An update on anomalously white cetaceans, including the first account for the pantropical spotted dolphin (Stenella attenuata graffmani). Latin Am. J. Aquat. Mamm. 3(2): 163-166.

Fertl, D.; Pusser, L.T. \& Long, J.J. 1999. First record of an albino bottlenose dolphin (Tursiops truncatus) in the Gulf of Mexico, with a review of anomalously white cetaceans. Mar. Mamm. Sci. 15(1): 227-234.

Fertl, D. \& Rosel, P.E. 2008. Albinism. In: Perrin, W. F.; Würsig, B. \& Thewissen, J. G. M. (eds.) Encyclopedia of marine mammals. $2^{\text {a }}$ Edition. Academic Press, San Diego. 24-26 pp.

Moreno, I. B.; Zerbini, A. N.; Danilewicz, D.; SimõesLopes, P. C.; Lailson-Brito, J. \& Azevedo, A. F. 2005. Distribution and habitat characteristics of dolphins of the genus Stenella (Cetacea: Delphinidae) in the southwest Atlantic Ocean. Mar. Ecol. Prog. Ser. 300: 229-240.
Perrin, W.F. 2002. Stenella frontalis. Mamm. Species. 702: 1-6.

Perrin, W.F.; Mitchell , E.D.; Mead, J.G.; Caldwell, D.K.; Caldwell, M. C.; van Bree, P. J. H. \& Dawbin , W. H. 1987. Revision of the spotted dolphins, Stenella spp. Mar. Mamm. Sci. 3(2): 99-170.

Stockin, K.A. \& Visser, I.N. 2005. Anomalously pigmented common dolphins (Delphinus sp.) off Northern New Zealand. Aq. Mamm. 3 (1): 43 -51.

Tonaya, A.M.; Bilginc, S; Dedea, A.; Akkayab, A.; Yesilcicekc, T.; Kosec, O.; \& Ceylanc, Y. 2012. First records of anomalously white harbour porpoises (Phocoena phocoena) in the Turkish seas with a global review. Hystrix. 23(2): 76-87.

Tsutsui, S.; Tanaka, M.; Miyazaki, N. \& Furuya, T. 2001. Pacific white-sided dolphins (Lagenorhynchus obliquidens) with anomalous colour patterns in Volcano Bay, Hokkaido, Japan. Aq. Mamm. 27(2): 172-182.

Van Waerebeek, K. 1993. External features of the dusky dolphin Lagenorhynchus obscurus (Gray, 1828) from Peruvian waters. Estud. Oceanol. 12: 37-53. 